\title{
Characterization of Proteins Induced by Herpesvirus saimiri: Comparative Immunoprecipitation and Analysis of Glycosylation
}

\author{
S. Modrow, H. Schmidt, and H. Wolf
}

Marmosets of the genus Saguinus ( $S$. nigricollis, S. fuscicollis, and $S$. oedipus) are highly susceptible to tumor induction by Herpesvirus saimiri and die from a rapidly growing neoplastic disease [1-3] following viral infection. Owl monkeys (Aotus trivirgatus) show a similar course of disease. The appearance of tumors in these animal is often delayed and about $20 \%$ of the owl monkeys do not develop tumors [4, 5]. Herpesvirus saimiri-infected New Zealand White Rabbits (NZWR) show a disease pattern similar to the primate tumors; the incidence of neoplastic disease after infection with $H$. saimiri ranges from $20 \%$ to $75 \%$ in different studies [6-8]. The specificity of antibodies in the various experimental and natural hosts (Saimiri scireus) was determined by immunoprecipitation of viral polypeptides obtained from owl monkey kidney (OMK) cells infected with $H$. saimiri in the presence of labeled precursors. Whereas we describe the unglycosylated virus-induced proteins involved in another report [9], we include in this report the description of the glycoproteins in $H$. saimiri-infected cells.

In this study, we infected OMK cells with $H$. saimiri (strain 11) and an attenuated mutant of $H$. saimiri, originally isolated by Schaffer [10]. At various times $(6-8 \mathrm{~h}$, $15-17 \mathrm{~h}$, and $24-26 \mathrm{~h}$ after infection), virus-induced cell proteins were labeled with ${ }^{35} \mathrm{~S}$-methionine $(20 \mu \mathrm{Ci} / \mathrm{ml})$ and the viral proteins were immunoprecipitated with various sera from infected animals (the sera from the natural host Saimiri sciureus and from infected owl monkeys were a gift from L. Falk, New England Primate Center). A class of early proteins was obtained from infected cells by treatment with azetidine (Sigma); they were precipitated with the same sera.

The protein profiles obtained after precipitation with sera from $H$. saimiri-infected experimental hosts (owl monkeys, white lip marmoset, and NZWR) differed from those obtained with sera from the natural hosts. Proteins precipitated with sera from Saimiri sciureus were mostly late proteins and components of the virion. Sera from the experimental hosts precipitated a limited number of proteins ( $\mathrm{p} 152$, p 127, p 115, p 80, p 55-57, p 53, and p 50). Three of them ( $\mathrm{p} 115, \mathrm{p} \mathrm{80}$, and p 55-57) were not found with sera of the natural hosts. p 115 and p 55-57 are already synthesized at an early stage after infection; the synthesis of $\mathrm{p} 115$, however, is inhibited by treatment with azetidine and thus may belong to a second group of early proteins. p 127 and p 152 are components of the viral capsid. Natural and experimental hosts of $H$. saimiri revealed distinct profiles, whereas some similarities existed among the various types of experimental hosts. The reason for the observed differences may be the expression of viral polypeptides in the various host cells or host-specific differences in the immune system. No difference could be detected between the patterns obtained with the oncogenic $H$. saimiri 11 and the attenuated strain (H. saimiri 11 att.).

In a second line of experiments, we characterized glycosylated proteins produced in $H$. saimiri-infected OMK cells. Two different methods were used: (1) in vivo labeling with ${ }^{14} \mathrm{C}$-glucosamine in a medium containing fructose instead of glu- 
cose and followed by immunoprecipitation; (2) in vitro labeling of the glycoproteins separated on SDS-polyacrylamide gels with ${ }^{125}$ I-labeled lectins. Both experiments showed a similar pattern of glycosylated viral proteins produced in infected cells and can be used interchangeably. Seven glycosylated proteins could be identified (p 152, p 140, p 127, p 88, p 67, p 53, p 50) with both methods.

\section{References}

1. Meléndez LV, Daniel MD, Hunt RD, Garcia FG (1968) An apparently new herpesvirus from primary kidney culture of the squirrel monkey (Saimiri sciureus). Lab Anim Care 18:374-381

2. Meléndez LV, Daniel MD, Garcia FG, Fraser CEO, Hunt RD, King NW (1969) Herpesvirus saimiri I. Further characterization studies of a new virus from the squirrel monkey. Lab Anim Care 19:372-397

3. Deinhardt F, Falk L, Wolfe L (1974) Simian herpesviruses and neoplasia. Adv Cancer Res 19: 167-205

4. Meléndez LV, Hunt RD, Daniel MD, Blake BJ, Garcia FG (1971) Acute lymphocytic leukemia in owl monkeys inoculated with herpesvirus saimiri. Science 171:1162-1163

5. Cicmanec JL, Loeb WF, Valerio MG (1974) Lymphoma in owl monkeys (Aotus trivirgatus) inoculated with herpesvirus saimiri: Clinical, hematological and pathologic finding. J Med Primatol 3:8-17

6. Daniel MD, Meléndez LV, Hunt RD, King NW, Anver W, Fraser CEO, Barahona HH, Baggs RB (1974) Herpesvirus saimiri VII. Induction of malignant lymphoma in New Zealand white rabbits. J Natl Cancer Inst 53: 1803-1807

7. Daniel MD, Hunt RD, DuBoise D, Silva D, Meléndez LV (1975): Induction of herpesvirus saimiri in New Zealand white rabbits inoculated intravenously. In: deThé G, Epstein MA, zur Hausen $\mathrm{H}$ (eds.) Oncogenesis and herpesviruses II, IARC, Lyon, pp 205-208

8. Rangan SRS, Martin LN, Enright FM, Allen WP (1976) Herpesvirus saimiri induced malignant lymphoma in rabbits. J Natl Cancer Inst 55: 1243-1246

9. Modrow S, Wolf H (1983) Herpesvirus saimiri-induced proteins in lytically infected cells, I. Time-ordered synthesis. J Gen Virol 64:37-46

10. Schaffer PA, Falk LA, Deinhardt F (1975) Attenuation of herpesvirus saimiri for marmosets after successive passage in cell culture at $39^{\circ} \mathrm{C}$. J Natl Cancer Inst 55: $1243-1246$ 